(c) American Dairy Science Association, 2005.

\title{
Use of Intravaginal Progesterone-Releasing Inserts in a Synchronization Protocol before Timed Al and for Synchronizing Return to Estrus in Holstein Heifers
}

H. Rivera, H. Lopez, and P. M. Fricke

Department of Dairy Science, University of Wisconsin, Madison 53706

\begin{abstract}
Holstein heifers $(\mathrm{n}=189)$ were submitted to a 42 -d artificial insemination (AI) period in which they underwent $\mathrm{AI}$ after once-daily evaluation of rubbed tail chalk. At the onset of the AI period (d 0), heifers were assigned randomly to receive synchronization of ovulation and timed AI (TAI; d 0: $100 \mu \mathrm{g}$ of GnRH; d 6: $25 \mathrm{mg}$ of $\mathrm{PGF}_{2 \alpha} ; \mathrm{d} 8: 100 \mu \mathrm{g}$ of $\mathrm{GnRH}+\mathrm{TAI}$ ) either without (GPG; $\mathrm{n}=95$ ), or with inclusion of a CIDR insert (CIDR; $\mathrm{n}=$ 94) from d 0 to 6 . No CIDR heifers received AI before d 8 compared with $24 \%$ of GPG heifers, and pregnancy rate per $\mathrm{AI}(\mathrm{PR} / \mathrm{AI})$ at $30 \mathrm{~d}$ after TAI did not differ between treatments. To synchronize return to estrus for heifers failing to conceive after TAI, heifers $(n=166)$ receiving TAI to first service were randomly assigned to receive no further treatment (control; $\mathrm{n}=85$ ) or receive a new CIDR insert between 14 and $20 \mathrm{~d}$ after TAI (Resynch; $\mathrm{n}=81$ ). No Resynch heifers received AI during CIDR treatment compared with $35 \%$ of control heifers, and the proportion of heifers receiving AI within $72 \mathrm{~h}$ after the day of CIDR removal was 78 vs. $50 \%$ for Resynch vs. control heifers, respectively. No treatment $\times$ inseminator interaction was detected at first or second AI; however, overall PR/AI was modest for heifers throughout the experiment due to poor performance of 2 of the 3 herd inseminators (14, 6, and 58\% PR/AI, respectively). Inclusion of CIDR inserts suppressed estrus during the TAI protocol with no reduction in PR/ AI. Resynchronization of estrus using CIDR inserts resulted in tighter synchrony of estrus among nonpregnant heifers compared with untreated controls.

(Key words: controlled internal drug-releasing insert, dairy heifer, timed artificial insemination, resynchronization)
\end{abstract}

Abbreviation key: CIDR = controlled internal drugreleasing insert, $\mathbf{G P G}=$ synchronization regimen using sequential injections of $\mathrm{GnRH}$ and $\mathrm{PGF}_{2 \alpha}$ to control

Received July 19, 2004

Accepted November 18, 2004.

Corresponding author: P. M. Fricke; e-mail: pmfricke@wisc.edu. luteal regression and ovulation for timed insemination, PR/AI = pregnancy rate per artificial insemination, $\mathbf{P}_{4}=$ progesterone, $\mathbf{T A I}=$ timed artificial insemination .

\section{INTRODUCTION}

Artificial insemination breeding programs have long been recommended for dairy producers that raise heifers for herd replacements because of the proven genetic and economic advantages of using AI compared with using natural service bulls for breeding dairy cattle. Unfortunately, only 62 to $68 \%$ of dairy heifers on US farms receive at least one AI service (Hogeland and Wadsworth, 1995). When asked to rank reasons for using natural service bulls to breed heifers, farmers listed "heifers not at a convenient location," "inadequate heat detection for AI," and "lack of time to supervise AI" among the most important factors contributing to this management practice (Erven and Arbaugh, 1987). Thus, estrus-synchronization protocols that include timed AI (TAI) to minimize reliance on estrus detection may increase use of AI for breeding dairy heifers (Peeler et al., 2004).

Ovsynch was the first protocol developed to successfully synchronize ovulation thereby allowing for a TAI in lactating dairy cows (Pursley et al., 1995). Unfortunately, dairy heifers respond poorly to Ovsynch and TAI, exhibiting a pregnancy rate per AI (PR/AI) 20 to 40\% lower than heifers receiving AI to a standing estrus (Schmitt et al., 1996; Pursley et al., 1997). The greater incidence of estrus before TAI in dairy heifers (18\%; Rivera et al., 2004) compared with lactating cows (6 to 9\%; Roy and Twagiramungu, 1996) likely accounts for the low PR/AI to TAI for dairy heifers. Reduced PR/AI likely occurs when heifers express premature estrus that is not detected, but receive a TAI that is too late relative to estrus for conception to occur. Thus, suppression of premature estrus expression during a GnRH$\mathrm{PGF}_{2 \alpha}$-based protocol for synchronization of ovulation may improve the practical implementation of these protocols as a reproductive management tool in dairy heifers. Furthermore, because some heifers submitted to TAI at first breeding will fail to conceive, a strategy to 
resynchronize estrus for second breeding may be useful for submitting heifers for second $\mathrm{AI}$ and further minimize time devoted to detection of estrus.

The objectives of the present study were to: 1) evaluate the effect of a controlled internal drug-releasing (CIDR) insert as a tool to increase the proportion of heifers submitted to TAI after a hormonal protocol to synchronize ovulation, and 2) determine the effect of CIDR inserts to resynchronize return to estrus for dairy heifers failing to conceive to first TAI. Our hypothesis was that inclusion of CIDR inserts between the first 2 injections of a GnRH-PGF ${ }_{2 \alpha}$-based synchronization protocol would suppress premature expression of estrus before $\mathrm{PGF}_{2 \alpha}$ treatment, and that resynchronization of estrus in nonpregnant heifers using CIDR inserts might result in tighter synchrony of estrus among heifers failing to conceive to first TAI.

\section{MATERIALS AND METHODS}

\section{Facilities and Management of Heifers}

This field trial was conducted on a custom dairy heifer growing operation located in central Wisconsin comprising approximately 4500 Holstein dairy heifers. Heifers from 11 locations arrived at the farm at around 5 mo of age and were sorted by age to different pens and managed until 13 mo of age in open dry lots throughout the year. Every 10 to $14 \mathrm{~d}$, a group of 80 to 100 heifers within 2 wk of turning 13 mo of age was moved to 1 of 4 AI-breeding pens, each with 100 selflocking head gates. Heifers were fed once daily (between 0630 and $1100 \mathrm{~h}$ throughout the AI breeding period) a TMR comprising corn silage, alfalfa haylage, potatoes, and mineral mix. Artificial insemination was conducted for a 42-d period based on rubbed tail chalk, which was applied and evaluated daily during the morning feeding period when heifers were restrained in the self-locking head gates. This experiment was conducted in 2 replicates $(\mathrm{n}=\sim 94$ heifers/replicate) from August 27 to September 10, 2002.

\section{Synchronization of Ovulation for First Al Service}

At onset of the AI breeding period (d 0), Holstein heifers were assigned randomly to receive $\mathrm{GnRH}$ (Cystorelin; Merial Ltd; Duluth, GA) and $\mathrm{PGF}_{2 \alpha}$ (Lutalyse; Pharmacia Animal Health, Kalamazoo, MI) as follows: $100 \mu \mathrm{g}$ of $\mathrm{GnRH}$ on d $0 ; 25 \mathrm{mg}$ of $\mathrm{PGF}_{2 \alpha}$ on d 6;100 $\mu \mathrm{g}$ of GnRH + TAI on d 8, either without (GPG; $\mathrm{n}=95)$ or with insertion of a new CIDR insert (Eazi-breed CIDR, Pharmacia Animal Health) containing $1.38 \mathrm{~g}$ of progesterone $\left(\mathbf{P}_{4}\right)$ from d 0 to $6(\mathrm{CIDR} ; \mathrm{n}=94)$. Heifers in both treatments received TAI within 30 min after the second GnRH injection. Any heifer in which tail chalk removal was detected before scheduled TAI on d 8 was inseminated and the subsequent synchronization protocol components were discontinued. Artificial insemination throughout the experiment was performed by the herd manager and 2 full-time employees. A maximum of 92 TAI were performed per replicate on $\mathrm{d} 8$ of the experiment.

\section{Synchronization of Estrus for Second Al Service}

On d 14 after TAI, heifers receiving TAI were assigned randomly within treatment (GPG and CIDR) to receive no further treatment (control; $n=85$ ) or to receive a new CIDR insert from d 14 to 20 after TAI (Resynch; $n=81$ ). All heifers were inseminated after rubbed tail chalk that was evaluated once daily at the morning feeding period when heifers were restrained in self-locking head gates.

\section{Blood Sampling and Radioimmunoassay}

Blood samples were collected from GPG and CIDR heifers via venipuncture of the median caudal vein or artery immediately before administration of the second $\mathrm{GnRH}$ injection of each protocol. Blood samples were allowed to clot for $24 \mathrm{~h}$ at $4^{\circ} \mathrm{C}$, and centrifuged (1500 $\times g$ for $15 \mathrm{~min}$ ). Blood serum was harvested and stored at $-20^{\circ} \mathrm{C}$ until assayed for $\mathrm{P}_{4}$ concentration by radioimmunoassay (Coat-a-Count Progesterone, Diagnostic Products Corporation, Los Angeles, CA). All samples were run in a single assay, and the intraassay coefficient of variation was $6.8 \%$. Serum samples were classified as either low ( $\leq 1.0 \mathrm{ng} / \mathrm{mL})$ or high $(>1.0 \mathrm{ng} / \mathrm{mL})$, to assess the presence (high $\mathrm{P}_{4}$ ) or absence (low $\mathrm{P}_{4}$ ) of a functional corpus luteum at the second $\mathrm{GnRH}$ injection. Blood sampling and hormone injections for heifers inseminated after removed tail chalk during the protocol were discontinued after AI.

\section{Transrectal Ultrasonography}

Ovarian structures were monitored using an ultrasound machine equipped with a transrectal $7.5-\mathrm{MHz}$ linear-array transducer (Aloka 500V; Corometrics Medical Systems, Inc., Wallingford, CT). During each ultrasound examination conducted on d 8 and 10, a sketch of the location and diameter of all ovarian structures $\geq 8 \mathrm{~mm}$ in diameter was recorded for all heifers receiving TAI. For each ovarian structure, 2 diameter measurements, taken at right angles, were recorded on a single frozen image of the presumed maximal diameter of the structure using the digital calipers of the ultrasound machine. Diameters were calculated as the mean of these 2 measurements. Ovulatory response after the 
second GnRH injection was determined by the presence of 1 or more dominant follicles at the time of the second GnRH injection and the absence of 1 (single ovulation) or 2 (double ovulation) of those follicles at an ultrasound examination conducted $48 \mathrm{~h}$ later (Fricke et al., 1998). Ultrasound examinations were conducted to determine diameter of the largest follicle at the time of CIDR removal in Resynch heifers (d 20 postTAI). Rate of double ovulation was calculated as the number of heifers that ovulated 2 follicles within $48 \mathrm{~h}$ of the second $\mathrm{GnRH}$ injection, and was expressed as a percentage of heifers that ovulated after the second GnRH injection. Synchronization rate was defined as the proportion of heifers with low $\mathrm{P}_{4}$ at the second GnRH injection, and in which ovulation occurred within $48 \mathrm{~h}$ after the second GnRH injection, expressed as percentage of the total number of heifers treated with the protocol.

\section{Pregnancy Rate per Al}

Pregnancy status was determined $30 \pm 0.1$ and 65 $\pm 0.1 \mathrm{~d}$ after TAI using transrectal ultrasonography. Visualization of a fluid-filled uterine horn and presence of a conceptus were used as positive indicators of pregnancy (Fricke et al., 1998). Pregnancy rate per artificial insemination to TAI assessed at 30 and $65 \mathrm{~d}$ after AI and pregnancy loss between these 2 stages of gestation were calculated for heifers in both treatments. Fetal sex was determined for all heifers confirmed pregnant at d 65 of gestation. A fetus was recorded as a male when the genital tubercle was located in the area caudal to the umbilicus and as a female when the same structure was located beneath the tail (Curran and Ginther, 1991).

\section{Body Size Traits}

Body condition scores were assigned to each heifer before first $\mathrm{AI}$ by the same evaluator throughout the experiment using a quarter-point scale from 1.0 to 5.0, where $1.0=$ emaciated and $5.0=$ obese (Ferguson et al., 1994). Live BW was estimated for each heifer before first AI using a commercial dairy tape (Weight-ByBreed Dairy Cow Tape; Nasco, Fort Atkinson, WI), and hip height and wither height were measured for each heifer at first AI on a level concrete surface with the heifer in a normal standing position. Wither height index was calculated as BW divided by wither height as described by Looper and Bethard (2000), but using metric rather than imperial units of measure.

\section{Statistical Analyses}

Dichotomous data (ovulatory response after GnRH and PR/AI) were analyzed by multifactorial logistic re- gression using the LOGISTIC procedure of SAS (SAS Institute, 1989). The model used to analyze PR/AI to first breeding included treatment, inseminator, and treatment $\times$ inseminator interaction, with BCS, wither height, hip height, and BW at first $\mathrm{AI}$ as regression variables. Because all heifers per replicate were 13 mo of age within a 2 -wk period, age was not included in the model.

To assess potential carryover effects of CIDR inserts used for first TAI on PR/AI to second AI, treatments from TAI (CIDR vs. GPG) and treatments from second AI (Resynch vs. control) were combined to yield 4 treatment groups for first/second AI (CIDR/CIDR, CIDR/ noCIDR, noCIDR/CIDR, noCIDR/noCIDR). Thus, the new model to analyze PR/AI to second AI included treatment, inseminator, and treatment $\times$ inseminator interaction. No difference in PR/AI was detected among these 4 treatments, possibly due to the small number of heifers in each of the 4 treatments. Because no statistical difference was detectable, however, PR/AI to second AI was analyzed using a model that included treatment (control vs. Resynch), inseminator, replicate, and the interaction of treatment $\times$ inseminator.

Continuous data (days to first AI, days to conception, and follicular diameter) were analyzed using the GLM procedure of SAS. Effect of treatment on interval to first AI and to pregnancy was evaluated by survival analysis using the Log-Rank method of the LIFETEST procedure of SAS including all heifers assigned to each treatment. The Log-Rank method also was used in survival analysis to evaluate interval to pregnancy including all heifers in the model. Heifers not inseminated during the breeding period were censored. Fetal sex ratio was analyzed by $\chi^{2}$ for specified proportions using the FREQ procedure of SAS. Because no published reports of the sex ratio of calves born to nulliparous Holstein heifers in the literature were found, the specified proportions (expected values) used in this analysis were based on the observed sex ratio of newborn calves reported by Ryan and Boland (1991) for primiparous Holstein dairy cows.

For all analyses, a significant difference was stated when $P \leq 0.05$, whereas a statistical tendency was considered to occur when $P=0.05$ and $\leq 0.10$.

\section{RESULTS AND DISCUSSION}

\section{Pregnancy Rate per Al}

Pregnancy rate per AI during the experiment was profoundly affected by variation among herd inseminators, which was characterized by an unacceptably low PR/AI for 2 of the 3 inseminators (Table 1). A similar effect of inseminator was reported in a field trial conducted on this farm (Rivera et al., 2004). Because 
Table 1. Effect of inseminator on pregnancy rate per artificial insemination (PR/AI) of Holstein dairy heifers during the 42-d AI breeding period.

\begin{tabular}{|c|c|c|c|c|}
\hline \multirow[b]{2}{*}{ Item } & \multicolumn{3}{|c|}{ Inseminator } & \multirow[b]{2}{*}{ Overall } \\
\hline & 1 & 2 & 3 & \\
\hline \multicolumn{5}{|l|}{ First insemination } \\
\hline $\mathrm{GPG}^{1}$ & $8(2 / 25)$ & $8(2 / 24)$ & $52(24 / 46)$ & $29(28 / 95)$ \\
\hline $\mathrm{CIDR}^{2}$ & $14(3 / 22)$ & $0(0 / 24)$ & $56(27 / 48)$ & $32(30 / 94)$ \\
\hline Total & $11^{\mathrm{a}}(5 / 47)$ & $4^{\mathrm{a}}(2 / 48)$ & $54^{\mathrm{b}}(51 / 94)$ & $31(58 / 189)$ \\
\hline \multicolumn{5}{|l|}{ Second insemination } \\
\hline Control $^{3}$ & $18(4 / 22)$ & $9(1 / 11)$ & $47(8 / 17)$ & $26(13 / 50)$ \\
\hline Resynch $^{4}$ & $19(3 / 16)$ & $11(1 / 9)$ & $79(19 / 24)$ & $47(23 / 49)$ \\
\hline Total & $18^{\mathrm{a}}(7 / 38)$ & $10^{\mathrm{a}}(2 / 20)$ & $66^{\mathrm{b}}(27 / 41)$ & $36(36 / 99)$ \\
\hline \multicolumn{5}{|l|}{ All inseminations } \\
\hline Overall & $14^{\mathrm{a}}(12 / 85)$ & $6^{\mathrm{a}}(4 / 68)$ & $58^{\mathrm{b}}(78 / 135)$ & $33(94 / 288)$ \\
\hline
\end{tabular}

\footnotetext{
${ }^{\mathrm{a}, \mathrm{b}}$ Within a row, percentages with different superscripts differ $(P<0.01)$. Treatment $\times$ inseminator interaction was not significant for first or second insemination.

${ }^{1}$ GPG heifers were subjected to a hormonal protocol for synchronization of ovulation and timed AI (TAI) for first service using sequential injections of $\mathrm{GnRH}(\mathrm{G})$ and $\mathrm{PGF}_{2 \alpha}(\mathrm{P})$ as follows: $\mathrm{d}$ 0: $100 \mu \mathrm{g}$ of $\mathrm{GnRH}$; $\mathrm{d}$ 6: $25 \mathrm{mg}$ of $\mathrm{PGF}_{2 \alpha}$; d 8: $100 \mu \mathrm{g}$ of GnRH + TAI.

${ }^{2}$ CIDR heifers were subjected to a hormonal protocol for synchronization of ovulation and TAI for first service as described for GPG heifers, but with the addition of a controlled internal drug-releasing (CIDR) insert from d 0 to 6.

${ }^{3}$ Control heifers received no further treatment after first TAI to synchronize return to estrus for second service.

${ }^{4}$ Resynch heifers received a CIDR insert between 14 and $20 \mathrm{~d}$ after first TAI to synchronize return to estrus for second service.
}

groups of heifers were enrolled into the present experiment (August 27 to September 10, 2002) immediately after completion of the enrolment phase of the preceding experiment (May 21 to August 13, 2002), we were unable to identify and mitigate the poor performance of the 2 herd inseminators before initiating the present experiment. Because treatment $\times$ inseminator interactions were not detected for pregnancy outcomes in the present experiment, main effects of treatment on experimental endpoints are valid. Moreover, the unacceptably low PR/AI in this field trial conducted on the largest commercial custom heifer growing operation in Wisconsin serves as a teaching opportunity for dairy farmers and the industry consultants who advise them.

\section{Effect of Inseminator on Pregnancy Rate per Al}

When overall PR/AI for the 3 inseminators in the present study was compared, the 2 herd employees had PR/AI of $14 \%(12 / 85)$ and 6\% (4/68) (inseminators 1 and 2 , respectively), which were less $(P<0.01)$ than that of the herd manager (inseminator 3), who had a PR/AI of 58\% (78/135; Table 1). No treatment $\times$ inseminator interaction was detected indicating that treatment effects on PR/AI in the present study were not confounded by the inseminator effect. Conception rates of dairy heifers inseminated after standing estrus have been reported to be $47 \%$ (Donovan et al., 2003), 59\% (Gwazdauskas et al., 1981), 55 to 66\% (Butler and Smith,
1989), and 74\% (Pursley et al., 1997). A recent study reported a $60 \%$ PR/AI for Jersey and Holstein heifers submitted to a TAI protocol using estradiol cypionate, $\mathrm{PGF}_{2 \alpha}, \mathrm{GnRH}$, and CIDR inserts (Peeler et al., 2004).

Few herd-level or animal-level factors affect fertility in dairy heifers (Donovan et al., 2003), and most herdlevel variation in conception rate in heifers is due to variation among inseminators and service sire (Ron et al., 1984). Barth (1993) reported that timing of AI, semen quality, semen handling, and inseminator expertise influenced pregnancy outcomes after AI in cattle. Improper semen placement in the reproductive tract also affects outcomes to AI with more than half of inseminators depositing semen into the cervix rather than correctly into the uterine body (Peters et al., 1984). A common mistake was for inseminators to deposit semen into the cervix while withdrawing the pipette or straw during AI (Zavy and Geisert, 1994). A similar effect of AI technician on conception rate was reported for beef heifers synchronized using melengestrol acetate and $\mathrm{PGF}_{2 \alpha}$ (Salverson et al., 2002). Had the herd manager inseminated all heifers in the present experiment, PR/AI would have been comparable with previous reports in dairy heifers (Gwazdauskas et al., 1981; Butler and Smith, 1989).

\section{Effect of Treatment on Synchronization and Pregnancy Outcomes to First AI Service}

A primary objective of the present experiment was to determine if inclusion of CIDR inserts from d 0 to 6 
(i.e., insertion at the first GnRH injection and removal at the $\mathrm{PGF}_{2 \alpha}$ injection) would suppress estrus during the protocol without negatively affecting fertility. As expected, none of the CIDR heifers displayed estrus during the protocol before scheduled TAI, whereas $24 \%$ of GPG heifers expressed estrus $4.5 \pm 0.4 \mathrm{~d}$ after the first GnRH injection (Figure 1, upper panel; Table 2). Similar observations were reported for dairy (Rivera et al., 2004) and beef (Roy and Twagiramungu, 1996) heifers subjected to protocols for synchronization of estrus when the GnRH injection was initiated at a random stage of the cycle followed $6 \mathrm{~d}$ later by $\mathrm{PGF}_{2 \alpha}$. No treatment difference was detected in ovulatory response to the second GnRH injection (Table 2). In the present study, $2 \%(3 / 146)$ of heifers that ovulated after the second GnRH injection ovulated 2 follicles, whereas the proportion of heifers carrying twin fetuses at $65 \mathrm{~d}$ of gestation was $2 \%(1 / 57)$. These results are consistent with previous reports of $1 \%$ double ovulation rates and $<1 \%$ twinning rates in dairy heifers (Ryan and Boland, 1991; Rivera et al., 2004). Synchronization rate (proportion of heifers on $\mathrm{d} 8$ having low $\mathrm{P}_{4}$ and subsequently ovulating a follicle after the second $\mathrm{GnRH}$ injection) was greater $(P<0.01)$ for CIDR heifers due to suppression of estrus during the protocol, whereas no treatment differences were detected for PR/AI at 30 or $65 \mathrm{~d}$ after AI or for pregnancy loss from 30 to $65 \mathrm{~d}$ after TAI (Table 2 ). Although fertility in the present experiment is less than that reported previously for this custom heifer growing operation (Rivera et al., 2004), the rate of pregnancy loss is similar between experiments, but greater than the $2 \%$ reported by Peeler et al. (2004) for Jersey and Holstein heifers during a similar stage of gestation.

Administering exogenous progestins in the absence of an active corpus luteum decreases fertility in cattle because of the development of persistent follicles (Anderson and Day, 1994; Fike et al., 1999). Excessive extension of the dominance period results in ovulation of an aged oocyte from a larger than normal ovulatory follicle that causes decreased conception rates at the synchronized estrus (Austin et al., 1999). In the present study, diameter of ovulatory follicles assessed at the second GnRH injection on d 8 did not differ between treatments $(11.5 \pm 0.2$ and $11.8 \pm 0.2 \mathrm{~mm}$ for CIDR and GPG, respectively; $P=0.65$ ) indicating that CIDR treatment did not allow excessive growth of preovulatory follicles. Based on data in lactating dairy cows, inclusion of a $\mathrm{GnRH}$ injection on d 0 would induce ovulation of a dominant follicle, if present, and initiation of a new follicular wave. If this physiology were similar in dairy heifers, the proportion of persistent follicles developing during the CIDR treatment would likely be minimal. In contrast, one study reported that few dominant follicles in dairy heifers likely ovulated in response to exogenous GnRH (Richardson et al., 2002). Lucy et al. (2001) reported similar PR/AI in dairy heifers after synchronization of estrus with CIDR for $7 \mathrm{~d}$ and $\mathrm{PGF}_{2 \alpha}$ treatment on d 6 compared with AI after synchronized estrus with $\mathrm{PGF}_{2 \alpha}$. Similarly, Martinez et al. (2002) reported improved pregnancy rates in beef heifers after addition of a progestin to a Cosynch or Ovsynch protocol.

Diameter of the largest follicle on d 8 affected $(P<$ $0.01)$ ovulatory response $(11.9 \pm 0.1$ and $9.8 \pm 0.4 \mathrm{~mm}$ for ovulatory and nonovulatory follicles, respectively), which is consistent with a previous report (Rivera et al., 2004). Growing ovarian follicles in lactating dairy cows generally must reach a minimum diameter of 10 $\mathrm{mm}$ before they acquire the capacity to ovulate to an injection of GnRH (Sartori et al., 2001). Interestingly, follicular diameter for heifers that ovulated after the second GnRH injection was greater $(P<0.01)$ for heifers diagnosed pregnant $30 \mathrm{~d}$ after TAI compared with nonpregnant heifers $(12.3 \pm 0.3$ and $11.3 \pm 0.2 \mathrm{~mm}$, respectively). Vasconcelos et al. (2001) reduced the size of the ovulatory follicle in lactating dairy cows submitted to Ovsynch by follicular aspiration and reported less serum concentrations of estradiol at the time of the second GnRH injection, subsequent diameter and volume of the $\mathrm{GnRH}$-induced corpus luteum, serum $\mathrm{P}_{4}$ concentrations, and fertility.

\section{Effect of Treatment on Second Al Service}

To determine the effect of using CIDR inserts to synchronize return to estrus for heifers failing to conceive after first service, heifers receiving TAI at first service were randomized within their original treatments and assigned to resynchronization treatments (85 and 81 for control and Resynch, respectively) for second AI (Table 3). Because 25 control heifers and 23 Resynch heifers were diagnosed pregnant $30 \mathrm{~d}$ after TAI, 60 and 58 nonpregnant heifers were eligible to receive second AI service in the control and Resynch treatments, respectively (Table 3). Although service rate for heifers eligible to receive a second AI was similar between treatments (Figure 2, upper panel; Table 3), the proportion of heifers receiving AI after rubbed tail chalk by $72 \mathrm{~h}$ after CIDR insert removal was greater $(P<0.01)$ for Resynch than for control heifers (Table 3). Furthermore, $35 \%$ (21/60) of nonpregnant control heifers were inseminated after rubbed tail chalk during the CIDR resynchronization period (Figure 2, upper panel), whereas none of the nonpregnant Resynch heifers were inseminated during the CIDR resynchronization period. Fewer noninseminated eligible heifers at the end of the experiment for control vs. Resynch heifers (illus- 

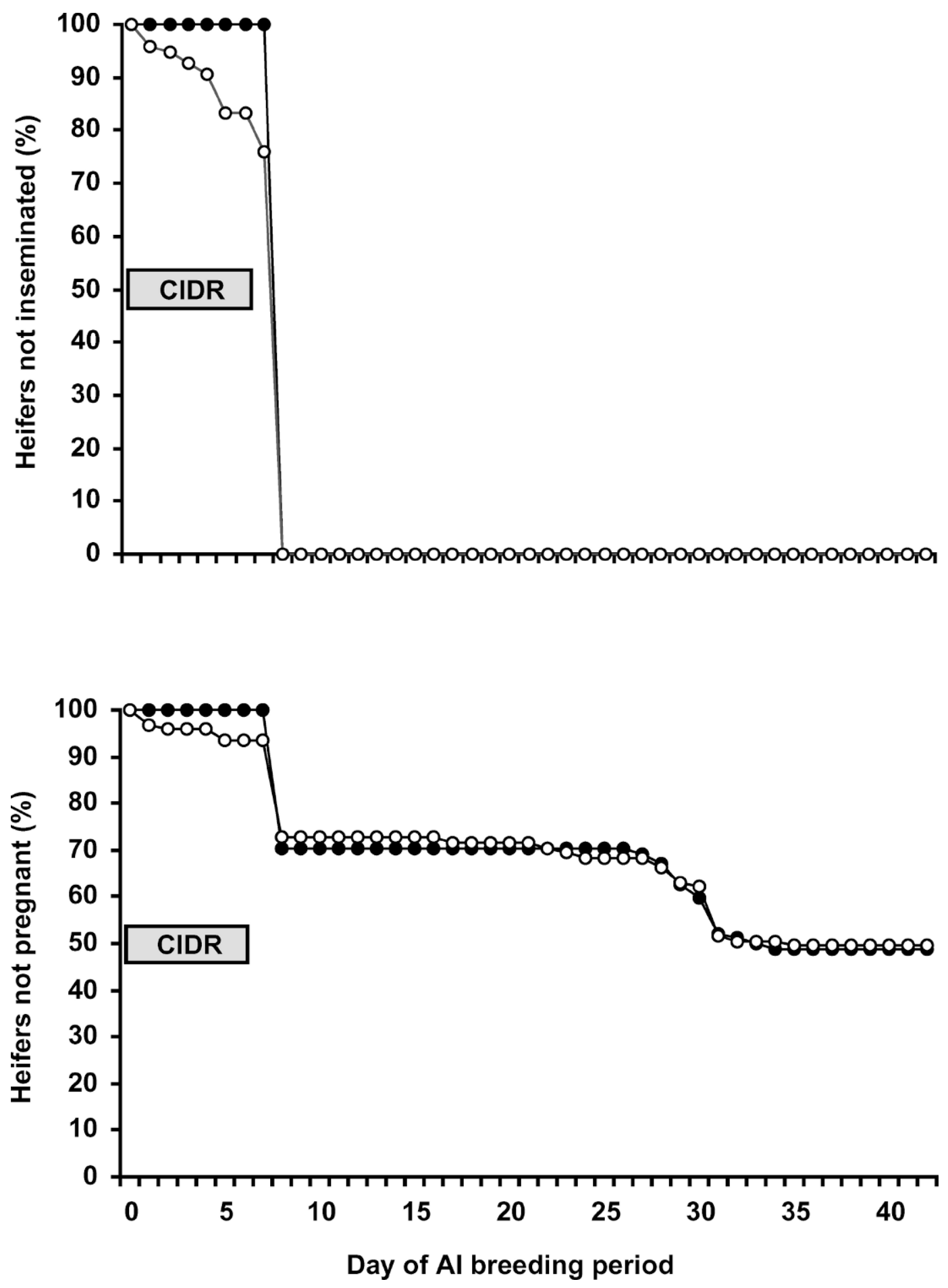

Figure 1. Effect of treatment on survival to first AI service (upper panel) and pregnancy (lower panel) during a 42 -d AI breeding period. Heifers were randomly assigned to receive either synchronization of ovulation and timed AI (open circles; GPG heifers; $\mathrm{n}=95 ; 100 \mu \mathrm{g}$ of $\mathrm{GnRH}$, d 0; $25 \mathrm{mg}$ of $\mathrm{PGF}_{2 \alpha}$, d 6;100 $\mu \mathrm{g}$ of GnRH+TAI d 8) or the GPG protocol with the addition of a CIDR insert from d 0 to 6 (filled circles; CIDR heifers; $n=94$ ). Heifers in both treatments were inseminated after rubbed tail chalk during the remainder of the AI breeding period. A treatment effect $(P<0.01)$ was detected for days to first AI service (upper panel). 
Table 2. Effect of treatments on synchronization response and pregnancy rate per artificial insemination (PR/AI) in Holstein dairy heifers after timed artificial insemination (TAI) at first service.

\begin{tabular}{|c|c|c|c|}
\hline \multirow[b]{2}{*}{ Item } & \multicolumn{2}{|c|}{ Treatment $^{1}$} & \multirow[b]{2}{*}{$P$ value } \\
\hline & GPG & CIDR & \\
\hline No. of heifers & 95 & \multirow{2}{*}{$\%($ no./total $) \stackrel{94}{-}$} & \\
\hline Synchronization response & & & \\
\hline Heifers receiving AI before d 8 & $24(23 / 95)$ & $0(0 / 94)$ & $<0.01$ \\
\hline Heifers ovulating after 2nd GnRH & $87(63 / 72)$ & $87(82 / 94)$ & 0.83 \\
\hline Heifers with low $\mathrm{P}_{4}$ on $\mathrm{d} 8^{2}$ & $92(66 / 72)$ & $98(92 / 94)$ & 0.07 \\
\hline Synchronization rate $^{3}$ & $62(59 / 95)$ & $86(81 / 94)$ & $<0.01$ \\
\hline Synchronized PR/AI & $31(18 / 59)$ & $33(27 / 81)$ & 0.85 \\
\hline \multirow{2}{*}{\multicolumn{4}{|c|}{$\begin{array}{l}\text { Fertility response } \\
\text { PR/AI to first AI at } 30 \mathrm{~d} \text { after } \mathrm{AI}\end{array}$}} \\
\hline & & & \\
\hline After TAI & $31(22 / 72)$ & $32(30 / 94)$ & 0.79 \\
\hline After rubbed tail chalk & $26(6 / 23)$ & - & - \\
\hline Overall & $29(28 / 95)$ & $32(30 / 94)$ & 0.75 \\
\hline $\mathrm{PR} / \mathrm{AI}$ to first $\mathrm{AI}$ at $65 \mathrm{~d}$ after $\mathrm{AI}$ & $27(26 / 95)$ & $30(28 / 94)$ & 0.74 \\
\hline Pregnancy loss, 30 to $65 \mathrm{~d}$ after AI & $7(2 / 28)$ & $7(2 / 30)$ & 0.97 \\
\hline
\end{tabular}

${ }^{1} \mathrm{GPG}$ heifers were subjected to a hormonal protocol for synchronization of ovulation and timed AI (TAI) using sequential injections of $\mathrm{GnRH}(\mathrm{G})$ and $\mathrm{PGF}_{2 \alpha}(\mathrm{P})$ as follows: d 0: $100 \mu \mathrm{g}$ of GnRH; d 6: $25 \mathrm{mg}$ of $\mathrm{PGF}_{2 \alpha}$; d 8: $100 \mu \mathrm{g}$ of GnRH + TAI. CIDR heifers were subjected to a hormonal protocol for synchronization of ovulation and TAI as described for GPG heifers, but with the addition of a controlled internal drug-releasing (CIDR) insert from d 0 to 6.

${ }^{2}$ Heifers with serum $\mathrm{P}_{4} \leq 1.0 \mathrm{ng} / \mathrm{mL}$ were defined as having low $\mathrm{P}_{4}$.

${ }^{3}$ Proportion of heifers with low $\mathrm{P}_{4}(\leq 1.0 \mathrm{ng} / \mathrm{mL})$ at the second $\mathrm{GnRH}$ injection and in which ovulation occurred within $48 \mathrm{~h}$ after the second $\mathrm{GnRH}$ injection expressed as a percentage of the total number of heifers receiving the protocol.

trated in Figure 3) is an artifact caused by a greater proportion of control than Resynch heifers receiving more than 2 inseminations.

Chenault et al. (2003) reported no difference in PR/ $\mathrm{AI}$ for dairy cows resynchronized with CIDR inserts from d 14 to 21 after first AI; however, PR/AI to the first service was reduced slightly after CIDR insertion for resynchronization. In the present study, no effect of CIDR reinsertion on PR/AI to first service was detected (31 and 32\% for GPG and CIDR, respectively; $P=0.86$ ). Hanlon et al. (1997) reported a similar PR/ AI to a resynchronized estrus in dairy heifers using
CIDR inserts for $5 \mathrm{~d}$ beginning 14 or $16 \mathrm{~d}$ after AI. In contrast to results in the present study, Xu and Burton (1999) reported reduced PR/AI after resynchronization with a CIDR insert in dairy heifers from 16 to $21 \mathrm{~d}$ after first AI. In the present study, CIDR inserts were removed $20 \mathrm{~d}$ after TAI to minimize the potential risk of developing persistent follicles and reducing fertility of the heifers that would have returned to estrus before $20 \mathrm{~d}$ after TAI. Unexpectedly, PR/AI to second AI was greater $(P<0.05)$ for Resynch than for control heifers (Table 3). Exposure to a CIDR insert for first service did not affect PR/AI to second service. Although a treat-

Table 3. Effect of treatments on AI service rate, timing of AI, and pregnancy rate per artificial insemination (PR/AI) for Holstein dairy heifers that were untreated (control) or in which return to estrus was synchronized using a CIDR insert (Resynch) after first AI.

\begin{tabular}{lll}
\hline & \multicolumn{2}{c}{ Treatment $^{1}$} \\
\cline { 2 - 2 } Item & Control & Resynch \\
\hline No. of heifers & 85 & 81 \\
\cline { 2 - 3 } & $71(60 / 85)$ & $72(58 / 81)$ \\
Heifers diagnosed nonpregnant to 1st service & $83(50 / 60)$ & $84(49 / 58)$ \\
AI service rate & $50(25 / 50)$ & $78^{\mathrm{a}}(38 / 49)$ \\
AI within 72 h after the day of CIDR removal & $26(13 / 50)$ & $47^{\mathrm{a}}(23 / 49)$ \\
PR/AI to resynchronization, 40 to 60 d after AI & &
\end{tabular}

${ }^{a}$ Differs from control $(P<0.05)$.

${ }^{1}$ Control heifers were re-inseminated for a second AI service after rubbed tail chalk, whereas Resynch heifers were resynchronized before a second AI service by inserting a CIDR insert from 14 to $21 \mathrm{~d}$ after timed AI at first service. 

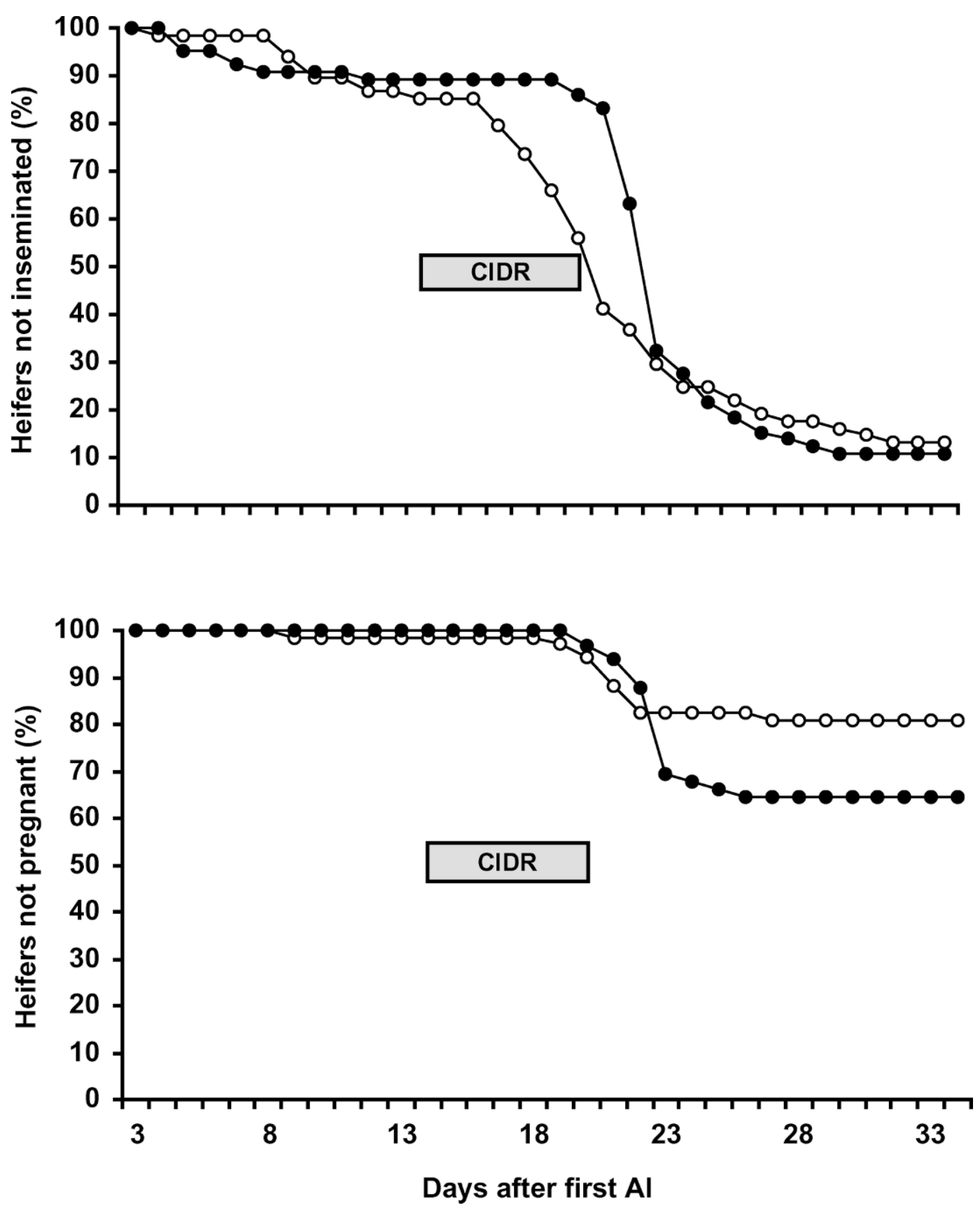

Figure 2. Effect of resynchronization treatment on time to second or third AI service (upper panel) and survival to pregnancy (lower panel) during a 42-d AI breeding period. Open circles = control heifers; filled circles = Resynch heifers. Heifers were randomly assigned to be re-inseminated after rubbed tail chalk (control, $\mathrm{n}=50$ ) or resynchronization of estrus with a CIDR insert from d 14 to 20 after TAI (Resynch; $\mathrm{n}=49$ ). Heifers were inseminated after both treatments based on rubbed tail chalk. A treatment effect $(P=0.05)$ was detected for days to pregnancy after second AI (lower panel).

ment $x$ inseminator interaction was not detected for second AI, inseminator 3 had a greater PR/AI for Resynch than for control heifers (Table 1). The possibility of Type I or Type II errors (declaring a difference when a difference among groups does not exist or declaring no difference when a difference exists), should be con- sidered when interpreting these data. The likelihood of detecting inseminator effects on fertility was limited in the present study because less than 50 breedings per treatment were included for inseminator 3. Further research is needed to determine the effect of this resynchronization strategy on fertility of dairy heifers. 

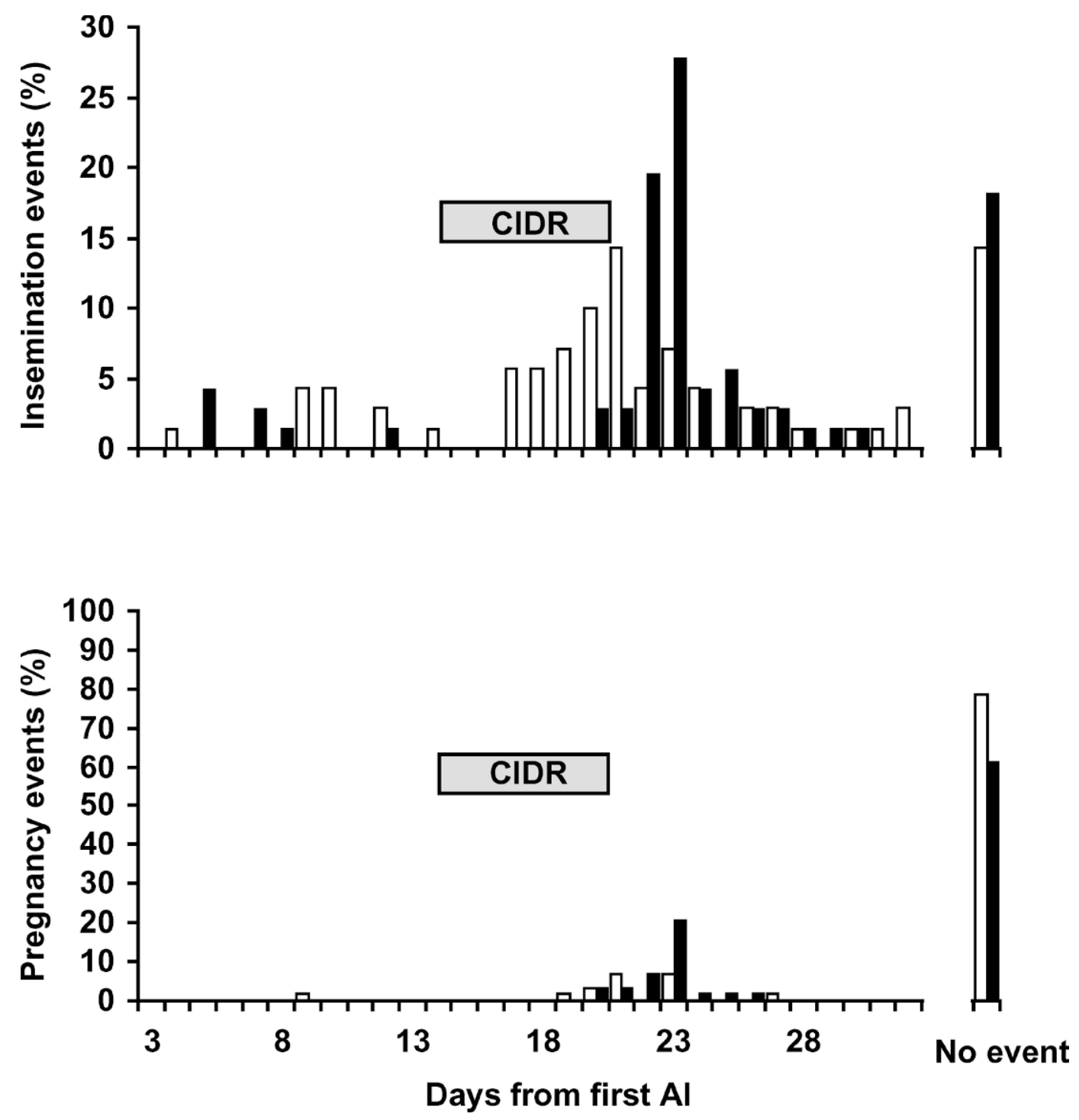

Figure 3. Frequency distribution of insemination events (\% of total inseminations) for second and greater AI service (upper panel) and pregnancy events (\% of total pregnancies) for heifers that conceived to second and greater AI service (lower panel). Heifers were assigned randomly to receive either no resynchronization treatment (control, $\mathrm{n}=50$; open bars) or resynchronization with a CIDR insert from d 14 to 20 after TAI (Resynch, $\mathrm{n}=49$; filled bars). Heifers in both treatments were re-inseminated after rubbed tail chalk throughout the breeding period. No Resynch heifers were re-inseminated while CIDR inserts were in place compared with $35 \%$ of control heifers. The proportion of heifers inseminated by $72 \mathrm{~h}$ after CIDR insert removal was 78 vs. 50\% for Resynch vs. control heifers, respectively.

Contrary to the effect of follicular size on PR/AI to TAI detected in this study, follicular size at the time of CIDR removal (assessed only in Resynch heifers) did not differ between Resynch heifers diagnosed pregnant vs. not pregnant $30 \mathrm{~d}$ after second AI (10.2 \pm 0.9 and $10.9 \pm 0.4 \mathrm{~mm}$, respectively). Assessment of follicular size in heifers submitted to TAI (i.e., synchronized ovulation) was performed at a known stage relative to the expected time of ovulation after $\mathrm{GnRH}$ treatment ( 28 to $30 \mathrm{~h}$ ). In contrast, Resynch heifers inseminated after rubbed tail chalk probably had larger follicles (greater than 10.2 to $10.9 \mathrm{~mm}$ ) at the time of AI compared with the time of CIDR removal, given that these follicles could have grown larger later on. Therefore, the smaller follicular size detected in heifers inseminated in the Resynch group compared with heifers receiving TAI, as well as the similar follicular size of pregnant vs. not pregnant Resynch heifers could be explained by the uncertain time from their CIDR insert removal to the endogenous GnRH/LH surge, which might affect the final stages of follicular growth. 
Heifers failing to conceive to TAI returned to second service beginning as early as $4 \mathrm{~d}$ after TAI; however, $\mathrm{P}_{4}$ concentration was not evaluated at second AI. A total of 16 nonpregnant heifers received a second service by $14 \mathrm{~d}$ after TAI, and only 1 of these heifers conceived (Figure 3). Because both luteal regression and ovulation in this heifer was synchronized by the protocol, but returned to service $9 \mathrm{~d}$ after TAI, it was assumed to have had a short luteal phase. From CIDR reinsertion (d 14) until 19 d after TAI, 14 nonpregnant control heifers were re-inseminated, compared with none of the Resynch heifers. Only 1 of these heifers became pregnant (d 19). Because PR/AI to second AI by $19 \mathrm{~d}$ after TAI was only $7 \%(2 / 30)$, most of these services likely represent timing of $\mathrm{AI}$ errors due to inaccurate detection of estrus based on rubbed tail chalk (Figure 3 ). Comparison of the percentage distribution of pregnancies after the second AI service (Figure 3, lower panel) to the percentage distribution of second AI services illustrates these trends. Although patterns of estrus behavior were not examined in the present study, Richardson et al. (2002) reported a decreased number and total duration of standing events for a second AI service when heifers were submitted to a synchronization protocol before first AI.

A surprisingly large proportion of pregnant heifers $(17 \% ; 10 / 58)$ were re-inseminated after the TAI, but before pregnancy diagnosis at $30 \mathrm{~d}$. Prevalence of this error was reported to be $8 \%$ for dairy heifers diagnosed pregnant approximately $30 \mathrm{~d}$ after AI (Rivera et al., 2004). Although the effect of this error on PR/AI was not evaluated, some heifers diagnosed nonpregnant 30 $\mathrm{d}$ after AI conceived to first AI and subsequently lost these pregnancies due to insemination after secondary signs of estrus. In fact, 1 of the heifers $(25 \%, 1 / 4)$ having pregnancy loss (diagnosed pregnant at $30 \mathrm{~d}$ and open at $65 \mathrm{~d}$ after TAI) received AI on d 22 of gestation. Unnecessary re-insemination during diestrus reduced the $\mathrm{PR} / \mathrm{AI}$ to a previous insemination at the correct time by over 30\% (Macmillan et al., 1977). Weaver et al. (1989) reported reduced PR/AI for cows re-inseminated in the uterine body between 12 and $24 \mathrm{~d}$ after previous inseminations at estrus (4 vs. $41 \%$ for re-inseminated and control, respectively). Artificial insemination during pregnancy may induce loss, through mechanical trauma to fetal membranes or from the introduction of infection (Noakes et al., 2001).

\section{Effect of Body Size Parameters}

No effect of body size traits on pregnancy status 30 $\mathrm{d}$ after first AI was detected in the present study. This supports the observation that animal-level factors are not strongly associated with fertility in dairy heifers
Table 4. Sex ratio of fetuses in Holstein dairy heifers at $65 \mathrm{~d}$ of gestation resulting from AI after rubbed tail chalk (AI) or timed artificial insemination (TAI) after a synchronized ovulation.

\begin{tabular}{lrlll}
\hline Item & No. & $\%$ female & $\%$ male & $P$ value $^{1}$ \\
\hline Current study & & & & \\
$\quad$ AI & 6 & 33 & 67 & 0.44 \\
TAI & 48 & 63 & 38 & 0.06 \\
Rivera et al., 2004 & & & & \\
$\quad$ AI & 78 & 51 & 49 & 0.68 \\
TAI & 48 & 54 & 46 & 0.47 \\
Overall & & & & \\
AI & 84 & 50 & 50 & 0.85 \\
TAI & 96 & 58 & 42 & 0.06 \\
\hline
\end{tabular}

${ }^{1}$ Observed sex ratio was compared with the expected sex ratio ( $51 \%$ male, $49 \%$ female) for newborn calves observed for primiparous Holstein dairy cows $(\mathrm{n}=7852)$ reported by Ryan and Boland (1991).

(Donovan et al., 2003). Overall, BW (377.5 $\pm 2.1 \mathrm{~kg})$, hip height $(131 \pm 0.7 \mathrm{~cm})$, and wither height $(122 \pm 0.3)$ were within body size recommendations by age reported for growing dairy heifers (Hoffman, 1997; Looper and Bethard, 2000). Heifers were evaluated using both wither height index $(3.1 \pm 0.0)$ and BCS $(3.0 \pm 0.0)$ to avoid a possible bias due to visual errors in BCS (Looper and Bethard, 2000).

\section{Fetal Sex Ratio}

Observed sex ratio at $65 \mathrm{~d}$ of gestation based on ultrasonographic location of the genital tubercle tended $(P=$ 0.06) toward more female fetuses compared with the expected sex ratio reported for primiparous dairy cows inseminated after a standing estrus (49\% female; $\mathrm{n}=$ 7852; Ryan and Boland, 1991). In the present study, the proportion of female fetuses resulting from TAI (diagnosed at $65 \mathrm{~d}$ of gestation) was 61 and $65 \%$ for CIDR and GPG heifers, respectively. In the present analysis, sex ratio was assumed to be an effect of timing of AI in relation to $\mathrm{GnRH}$ treatment (i.e., ovulation), and it was not expected to differ between treatments. Therefore, sex ratio data from both treatments was combined (Table 4). Data from the present study were combined with sex ratio data from a previous study (Rivera et al., 2004) that used the same breeding protocol for TAI. Overall, there was a tendency $(P=0.06)$ for heifers receiving TAI to have more female fetuses compared with the expected sex ratio reported for primiparous cows (Ryan and Boland, 1991). Increasing the interval from TAI to ovulation by synchronizing ovulation has been reported to skew the sex ratio to increase the number of female calves born in dairy cattle (Pursley et al., 1998; Xu and Burton, 1999). Further research is needed to determine the effect of time of $\mathrm{AI}$ relative to ovulation on sex ratio in dairy heifers. 


\section{CONCLUSION}

Inclusion of CIDR inserts in a protocol to synchronize ovulation suppressed estrus during CIDR insertion, thereby allowing a $100 \%$ submission rate for TAI without affecting fertility. Due to the significant inseminator effect detected in this study, overall pregnancy outcomes do not reflect results that could be attained for dairy heifers managed under optimal conditions. In contrast, the excellent synchronization response in this study demonstrates that inclusion of a CIDR insert into the GPG protocol may be successfully implemented when detection of estrus is a limiting factor for AI programs in dairy heifers. Use of CIDR inserts for resynchronization of return to estrus for heifers failing to conceive to first TAI resulted in a tighter synchrony of estrus among heifers, and may help avoid errors in timing of AI due to inherent inaccuracies of submitting heifers for AI based on rubbed tail chalk.

\section{ACKNOWLEDGMENTS}

We thank Pharmacia Animal Health for providing Lutalyse and CIDR inserts and Merial Ltd. for providing Cystorelin for this project. We also thank Jill Colloton of Bovine Services, LLC for her assistance with fetal sex determination. This research was supported by Hatch project WIS04431 to PMF.

\section{REFERENCES}

Anderson, L. H., and M. L. Day. 1994. Acute progesterone administration regresses persistent dominant follicles and improves fertility of cattle in which estrus was synchronized with melengestrol acetate. J. Anim. Sci. 72:2955-2961.

Austin, E. J., M. Mihm, M. P. Ryan, D. H. Williams, and J. F. Roche. 1999. Effect of duration of dominance of the ovulatory follicle on onset of estrus and fertility in heifers. J. Anim. Sci. 77:2219-2226.

Barth, A. D. 1993. Factors affecting fertility with artificial insemination. Vet. Clin. North Am. Food Anim. Pract. 9:275-289.

Butler, W. R., and R. D. Smith. 1989. Interrelationships between energy balance and postpartum reproductive function in dairy cattle. J. Dairy Sci. 72:767-783.

Chenault, J. R., J. F. Boucher, K. J. Dame, J. A. Meyer, and S. L. Wood-Follis. 2003. Intravaginal progesterone insert to synchronize return to estrus of previously inseminated dairy cows. J. Dairy Sci. 86:2039-2049.

Curran, S., and O. J. Ginther. 1991. Ultrasonic determination of fetal gender in horses and cattle under farm conditions. Theriogenology 36:809-814.

Donovan, G. A., F. L. Bennett, and S. P. Frederick. 2003. Factors associated with first service conception rates in artificially inseminated nulliparous Holstein heifers. Theriogenology 60:67-75.

Erven, B. L., and D. Arbaugh. 1987. Artificial insemination on U.S. dairy farms. Report of a study conducted in cooperation with the National Association of Animal Breeders. NAAB, Columbia, MO.

Ferguson, J. D., D. T. Galligan, and N. Thomsen. 1994. Principal descriptors of body condition score in Holstein cows. J. Dairy Sci. 77:2695-2703.

Fike, K. E., M. E. Wehrman, B. R. Lindsey, E. G. Bergfeld, E. J. Melvin, J. A. Quintal, E. L. Zanella, F. N. Kojima, and J. E. Kinder. 1999. Estrus synchronization of beef cattle with a combination of melengestrol acetate and an injection of progesterone and 17 betaestradiol. J. Anim. Sci. 77:715-723.

Fricke, P. M., J. N. Guenther, and M. C. Wiltbank. 1998. Effect of decreasing the dose of GnRH used in a protocol for synchronization of ovulation and timed AI in lactating dairy cows. Theriogenology 50:1275-1284.

Gwazdauskas, F. C., J. A. Lineweaver, and W. E. Vinson. 1981. Rates of conception by artificial insemination in dairy cattle. J. Dairy Sci. 64:358-362.

Hanlon, D. W., N. B. Williamson, I. J. Steffert, J. J. Wichtel, and D. U. Pfeiffer. 1997. Re-insertion of a progesterone-containing intravaginal device to synchronise returns to oestrus in dairy heifers. N.Z. Vet. J. 45:15-18.

Hoffman, P. C. 1997. Optimum body size of Holstein replacement heifers. J. Anim. Sci. 75:836-845.

Hogeland, J. A., and J. J. Wadsworth. 1995. The role of artificial insemination on U.S. dairy farms survey report. Study conducted in cooperation with the National Association of Animal Breeders. NAAB, Columbia, MO.

Looper, M., and G. Bethard. 2000. Management considerations in Holstein heifer development. College of Agriculture and Home Economics-Cooperative Extension Service, New Mexico State University, Las Cruces, NM. Guide B-118.

Lucy, M. C., H. J. Billings, W. R. Butler, L. R. Ehnis, M. J. Fields, D. J. Kesler, J. E. Kinder, R. C. Mattos, R. E. Short, W. W. Thatcher, R. P. Wettemann, J. V. Yelich, and H. D. Hafs. 2001. Efficacy of an intravaginal progesterone insert and an injection of $\mathrm{PGF}_{2 \alpha}$ for synchronizing estrus and shortening the interval to pregnancy in postpartum beef cows, peripubertal beef heifers, and dairy heifers. J. Anim. Sci. 79:982-995.

Macmillan, K. L., E. D. Fielden, and R. Curnow. 1977. Factors influencing AI conception rates. VIII. Effects of non-estrus insemination and return patterns after second inseminations. N.Z. J. Exp. Agric. 5:123-127.

Martinez, M. F., J. P. Kastelic, G. P. Adams, B. Cook, W. O. Olson, and R. J. Mapletoft. 2002. The use of prostaglandin in regimes for fixed-time artificial insemination in beef cattle. Theriogenology 57:1049-1059.

Noakes, D. E., T. J. Parkison, and G. C. W. England. 2001. Pages 497-499 in Arthur's Veterinary Reproduction and Obstetrics, 8th ed. Harcourt Publishers Ltd., London, UK.

Peeler, I. D., R. L. Nebel, R. E. Pearson, W. S. Swecker, and A. Garcia. 2004. Pregnancy rates after timed AI of heifers following removal of intravaginal progesterone inserts. J. Dairy Sci. 87:2868-2873.

Peters, J. L., P. L. Senger, J. L. Rosenberger, and M. L. O'Connor. 1984. Radiographic evaluation of bovine artificial insemination technique among professional and herdsman-inseminators using .5 and .25-ml French straws. J. Anim. Sci. 59:1671-1683.

Pursley, J. R., M. O. Mee, and M. C. Wiltbank. 1995. Synchronization of ovulation in dairy cows using $\mathrm{PGF}_{2 \alpha}$ and $\mathrm{GnRH}$. Theriogenology 44:915-923.

Pursley, J. R., R. W. Silcox, and M. C. Wiltbank. 1998. Effect of time of artificial insemination on pregnancy rates, calving rates, pregnancy loss and gender ratio after synchronization of ovulation in lactating dairy cows. J. Dairy Sci. 81:2139-2144.

Pursley, J. R., M. C. Wiltbank, J. S. Stevenson, J. S. Ottobre, H. A. Garverick, and L. L. Anderson. 1997. Pregnancy rates per artificial insemination for cows and heifers inseminated at a synchronized ovulation or synchronized estrus. J. Dairy Sci. 80:295-300.

Richardson, A. M., B. A. Hensley, T. J. Marple, S. K. Johnson, and J. S. Stevenson. 2002. Characteristics of estrus before and after first insemination and fertility of heifers after synchronized estrus using GnRH, $\mathrm{PGF}_{2 \alpha}$, and progesterone. J. Anim. Sci. 80:27922800 .

Rivera, H., H. Lopez, and P. M. Fricke. 2004. Fertility of Holstein dairy heifers after synchronization of ovulation and timed AI or AI after removed tail chalk. J. Dairy Sci. 87:2051-2061.

Ron, M., R. Bar-Anan, and G. R. Wiggans. 1984. Factors affecting conception rates of Israeli Holstein cattle. J. Dairy Sci. 67:854860. 
Roy, G. L., and H. Twagiramungu. 1996. A fixed-time AI program using the GnR-PGF ${ }_{2 \alpha}-\mathrm{GnRH}$ method for beef females. J. Anim. Sci. 74(Suppl. 1):462. (Abstr.)

Ryan, D. P., and P. M. Boland. 1991. Frequency of twin births among Holstein-Friesian cows in a warm dry climate. Theriogenology 36:1-10.

Salverson, R. R., J. M. DeJarnette, C. E. Marshall, and R. A. Wallace. 2002. Synchronization of estrus in virgin beef heifers using melengestrol acetate and $\mathrm{PGF}_{2 \alpha}$ : An efficacy comparison of cloprostenol and dinoprost tromethamine. Theriogenology 57:853-858

Sartori, R., P. M. Fricke, C. P. Ferreira, O. J. Ginther, and M. C. Wiltbank. 2001. Follicular deviation and acquisition of ovulatory capacity in bovine follicles. Biol. Reprod. 65:1403-1409.

SAS Institute. 1989. User's Guide: Statistics, Version 6, 4th ed. SAS Inst., Inc., Cary, NC.
Schmitt, E. J.-P., T. Diaz, M. Drost, and W. W. Thatcher. 1996. Use of a gonadotropin-releasing hormone agonist or human chorionic gonadotropin for timed insemination in cattle. J. Anim. Sci. 74:1084-1091.

Vasconcelos, J. L. M., R. Sartori, H. N. Oliveira, J. G. Guenther, and M. C. Wiltbank. 2001. Reduction in size of the ovulatory follicle reduces subsequent luteal size and pregnancy rate. Theriogenology 56:307-314.

Weaver, L. D., C. A. Daley, and C. L. Borelli. 1989. Effect of pregnancy rate of nonestrus insemination in previously inseminated dairy cows. Theriogenology 32:603-605.

Xu, Z. Z., and L. J. Burton. 1999. Reproductive performance of dairy heifers after estrus synchronization and fixed-time artificial insemination. J. Dairy Sci. 82:910-917.

Zavy, M. T., and R. D. Geisert. 1994. Pages 3, 5, 109-110 in Embryonic Mortality in Domestic Species. CRC Press Inc., Boca Raton, FL. 